\title{
Response of Material Properties of Flexible Pavements to Moisture Resulting from Poor Drainage Conditions: Case of Niger Delta Region of Nigeria
}

\author{
Enwuso Aleruchi Igwe* \\ Department of Civil Engineering \\ Rivers State University of Science and Technology, Nkpolu Oroworukwo \\ P.M.B 5080, Port Harcourt, Rivers State, Nigeria
}

*Corresponding Author: Enwuso Aleruchi Igwe, Department of Civil Engineering, Rivers State University of Science and Technology, Nkpolu Oroworukwo P.M.B 5080, Port Harcourt, Rivers State, Nigeria

\begin{abstract}
Asphalt concretes were prepared in the laboratory in submerged conditions to represent submerged conditions of flexible pavements having poor drainage conditions. The study investigated the behavioural changes that will occur in the material properties of a typically submerged flexible pavement for five days using simulations of hot mix asphalt concretes in the laboratory. Results obtained revealed that the percentage change in swell after day 5 immersion was $4.1 \%$ increase. Similarly, percentage change in tensile strain was $85.8 \%$ increase, whereas percentage change in stability was $36.2 \%$ reduction. Finally, percentage change in elastic modulus was $65.7 \%$ reduction and percentage change in fatigue life was $67.7 \%$ reduction.
\end{abstract}

Keywords: Material response, drainage, moisture and flexible pavement

\section{INTRODUCTION}

Road pavements are one of the largest infrastructure components in most of the developed nations of the world (Kim, 2008). For example nations such as France, United Kingdom, Denmark, Italy, Luxembourg, Austria, Ireland, Jordan, Israel, Slovenia and Germany have 100\% completely paved roads as at 2007 (http://www.nationmaster). These facts buttress the need for the science and technology of road pavements. Moreover, without an adequate transport system many economies of the developed nations will be grounded because the movement of goods and services will be scuttled.

It is common knowledge to say that nearly every form of transportation system apart from sea transportation will require a road pavement; thus, the need for proper pavement analysis, assessment, performance and maintenance.

Typically flexible pavements are complex in nature such that its composition is multi-layered; consisting of different materials, having various combinations and configurations of frequency of traffic loading that are mostly irregular. Also they are subjected to varying environmental conditions; and in particular temperature, moisture and oxidation rates (Robbins, 2009 \& Igwe et al., 2009). Hence, in reality predicting a long-term service life of asphalt pavements is one of the most challenging tasks for pavement engineers in Highway Engineering.

However, it is pertinent to say that a common knowledge exist amongst pavement engineers that the performance of flexible pavement is closely related to the performance of asphalt concrete. Thus, many times in pavement engineering flexible pavement performance is constantly being simulated using asphalt (bituminous) concretes in the laboratory; which the current study had adopted.

\subsection{Pavement Submergence in the Niger Delta due to Poor Drainage Conditions}

There is a growing concern with regards to quality of road pavements within the Niger Delta Region of Nigeria especially due to the effects of heavy rainfall that submerge the pavements without run-offs to drains. In practice flexible pavements should be designed and constructed along with drainage 
Response of Material Properties of Flexible Pavements to Moisture Resulting from Poor Drainage Conditions: Case of Niger Delta Region of Nigeria

infrastructures to help convey run-offs from pavement to channelized outlets. Some of the functions of a well constructed and maintained drainage system which is vital to proper functioning of road pavements should include:

- To convey rainwater from the surface of the carriageway to outfalls (streams and turnouts);

- Control the level of the water table in the sub-grade beneath the carriageway

- Intercept surface water flowing towards the road

- Convey water across the line of the road in a controlled fashion

However, it is noteworthy by observations that most of the roads in the Region (Trunk A, B and C) suffer submergence for many days sometimes weeks after sustained heavy rain falls. The reasons for submergence are not farfetched and resulting from a number of drainage problems as listed below.

- Drainage kerb higher than the road pavement with no water outlet from pavement to drains (See Figure 1)

- Blocked drainages due to deliberate act of disposing debris into drains (See figure 2)

- Deposition of silt and vegetation in the bottom of drains and culverts, often reducing the gradient (See Figure 3)

- No drainages at all (See Figure 4)

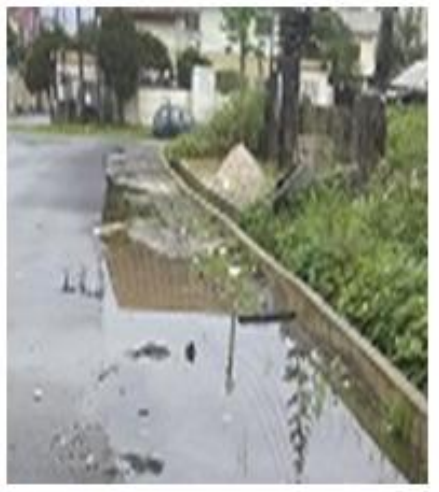

Figl.Kerb higher than the pavement without inlets

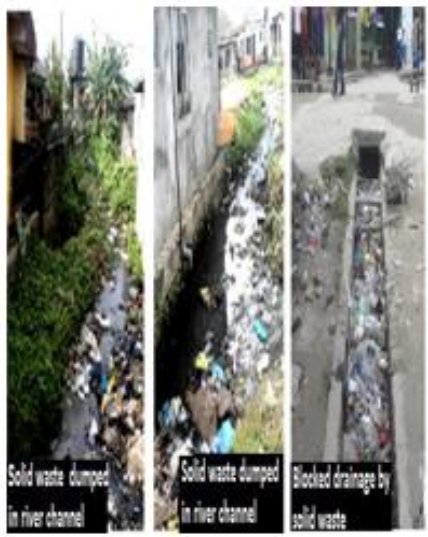

Fig3. Blocked drains by vegetation

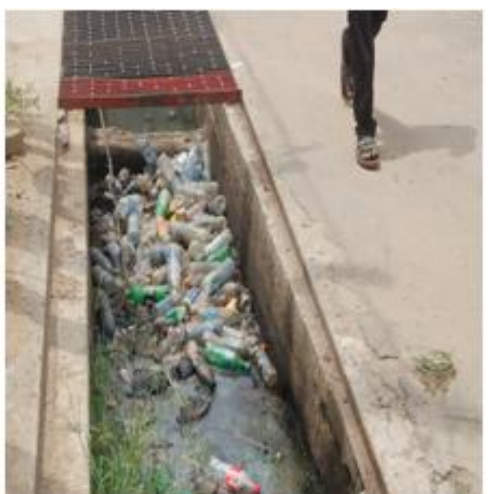

Figure2. Blocked Drainage by debris

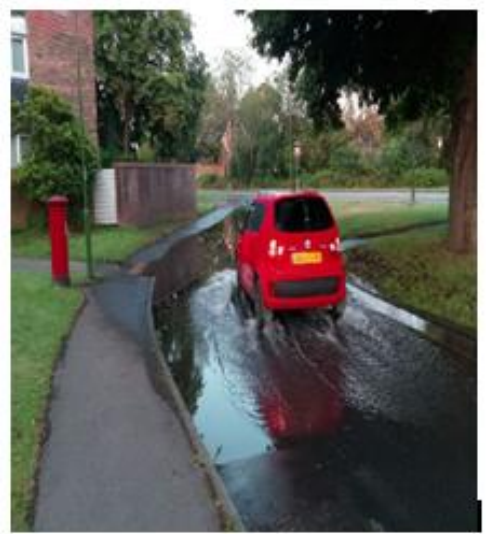

Fig4. No Drainage at all

\subsection{Material Response}

For purpose of the study the material properties investigated as result of moisture submergence resulting from poor drainage conditions includes;

- Stability from mix design properties

- Tensile strains and elastic modulus from elastic properties

International Journal of Constructive Research in Civil Engineering (IJCRCE) 
- Swell, retained stability and durability index from durability properties

- Fatigue life

\subsubsection{Stability}

Stability is defined as the maximum load resistance in Newton that a pavement will offer until failure occurs. The same is true using asphalt concrete samples for simulation in the laboratory to represent actual pavements in the field. Their stability determined as the maximum load resistance in Newton that the specimen will develop at $60{ }^{\circ} \mathrm{C}$ when compressed between two curved holders loaded at a rate of deformation of $50 \mathrm{~mm} /$ minute until failure occurs.

\subsubsection{Elastic Modulus}

The elastic modulus of a material is simply defined as the ratio of stress to strain within the elastic region and is also known as Young's modulus of elasticity. Furthermore, it is a measure of the linear stiffness of a material subjected to applied load or stress within the elastic region of the material (Emesiobi, 2000).

\subsubsection{Fatigue}

The damage occurring in a material due to the application of cyclic loading is called fatigue.

There are two aspects of fatigue namely- fatigue life and fatigue crack. The former is defined in terms of the total number of design load repetitions that a pavement will accommodate within the design and serviceability periods.

\subsubsection{Durability}

Asphalt pavement durability can be defined as its resistance to weathering and the abrasive action of traffic (Putri and Suparma, 2010). In addition, when considering its application to asphalt paving materials, it can be further defined as the ability of the paving materials in the asphalt pavement structure to withstand the effects of environmental conditions, such as water, ageing, temperature variations and oxidation without any excessive deterioration during design life of the pavement under varying traffic conditions of loading.

Lee (1969) previously affirmed that all bituminous paving materials change with time and under the action of heat, weather, and traffic. Furthermore, such changes are in general detrimental to their function as binders and as waterproofing agents; and that the degree of resistance of a bituminous binder to these changes is referred to as its durability. For purpose of the study durability parameters includes; - swell, retained stability and durability index.

Although many factors may contribute to flexible pavement failure in the Niger Delta Region of Nigeria as would include temperature cycle variations, irregular traffic loadings and tyre configurations, quality of aggregates and bitumen used for construction, poor workmanship, and method of awarding contracts and so on. However, the focus of this lecture is to bring to mind one of the most damaging contributors to flexible pavement failures in the Niger Delta Region which is pavement submergence in moisture resulting from a number of drainage problems already listed above. The foremost impact of moisture on flexible pavement is the defect called "STRIPPING". Stripping is moisture induced damage on pavements defined as the weakening or eventual loss of the adhesive bond between the aggregate surface and the asphalt binder in a Hot Mix Asphalt Concrete (HMA) pavement or mixture, usually under the presence of moisture (Mehari, 2007). Furthermore, the resistance of pavements to moisture damage under the presence of moisture in the mixture is a complex matter and the degree mainly depends on the properties of each ingredient materials in the mixture, type and use of mix, environment, traffic, construction practice, and the use of anti-strip additives.

In lay terms stripping would mean a separation of the asphalt binder from aggregates due to moisture intrusion. The effect of stripping however is three dimensional in that as separation gets further in the pavement due to moisture intrusion; tensile strains become increased leading to high voids in the pavement layer thereby causing loss in pavement stiffness. The implication of the above three defects is that the pavement gains moisture and swells, thus reducing stability and in turn reduces durability and ultimately creates fatigue cracks leading to failure. 
As long as this phenomena remains constant in the pavement the effect of traffic loading on the pavement become more catastrophic leading to early aging, brittility, breakage and ultimately failure.

It is noteworthy that at the instance of these three dimensional maladies (increased tensile strains, high voids and loss in stiffness) both durability and fatigue life are already compromised. Other problems include excessive roughness which sometimes leads to potholes when not attended to.

\section{Materials And Methods}

\subsection{Sample Collection}

The materials used for this study were asphalt cement, coarse and fine aggregates. The asphalt cement used was obtained from a Julius Berger Construction Company Rivers State, Nigeria On the other hand the coarse and fine aggregate used were obtained directly from market dealers at Mile 3, Diobu, Port Harcourt, rivers State, Nigeria. After sampling of the materials, laboratory tests - specific gravity, grading of asphalt and sieve analysis of the aggregates used for mix-proportioning by straight line method - were carried out.

\subsection{Sample Preparation}

Sample preparation was preceded by aggregate gradation and blending. The straight line method of blending which allows for only two aggregates to be blended was adopted. After aggregate gradation and blending Marshal Design Procedures for asphalt concrete mixes as presented in Asphalt Institute (1981), National Asphalt Pavement Association (1982) and Roberts et al (1996) was adopted for mix design. For the poor drainage condition asphalt concretes samples were prepared in similar manner to the control mixes followed by immersion between 1-5days concurrently.

\subsection{Assessment of Material Properties of Submerged Flexible Pavement using Laboratory Simulation of Hot Mix Asphalt Concretes}

For the purpose of assessing the durability of a typical flexible pavement that is submerged in moisture for a period of 5 days asphalt concrete samples were prepared using specified Marshal Standards (Asphalt Institute Manual Series, 1984) to simulate flexible pavements in reality.

The indices used for the measurement of durability were swell parameters using swell index (SI), retained stability using retained stability index (RSI) and durability index using first durability index (FDI).

\subsubsection{Swell Index}

Swelling index can simply be defined as the percentage increase in the volume of the pavement as a result of absorption of water after submergence for a period of time. It was obtained using Equations 1 - 4 below;

$$
S I=\left(\frac{V_{1}-V_{0}}{V_{0}}\right) * 100
$$

Where; V0 = Volume of sample before soaking

$\mathrm{V} 1=$ Volume of sample after soaking

Also

$V_{1}=W_{a 1}-W_{w 1}$

And

$V_{0}=W_{a 0}-W_{w 0}$

Therefore;

$S I=\left[\frac{\left(W_{a 1}-W_{w 1}\right)-\left(W_{a 0}-W_{w 1}\right)}{\left(W_{a 0}-W_{w 0}\right)}\right] * 100$ 
Where;

$\mathrm{Wa} 0=$ Weight in air before soaking

Wa1 $=$ Weight in air after soaking

$\mathrm{Ww} 0=$ Weight in water before soaking

$\mathrm{Ww} 1=$ Weight in water after soaking

\subsubsection{Retained Stability Index}

Retained Stability Index (RSI) is a measure of the loss of stability due to moisture in a pavement. It is used to measure the percentage of stability retained after a given period of submergence represented by Equation 5 below;

$$
R S I=\left(\frac{S_{1}}{S_{0}}\right) * 100
$$

Where;

RSI = Retained Stability Index

S0 $=$ stability before immersion or stability of unconditioned specimen

$\mathrm{S} 1$ = stability after immersion at a given time or stability of conditioned specimen

\subsubsection{Durability Index Using First Durability Index}

Craus et al (1981) defined Durability Index using the First Order (FDI) as the sum of the slopes of the consecutive sections of the durability curves and obtained as presented in Equation 6 below;

$$
F D I=\sum_{i=0}^{n-1} \frac{S_{i}-S_{i+1}}{t_{i+1}-t_{i}}
$$

Where;

$\mathrm{Si}=$ Percent Retained Stability at time ti

$\mathrm{Si}+1=$ Percent Retained Stability at time ti+1

ti+1 and $\mathrm{ti}=$ immersion times

\subsection{Assessment of Fatigue Life of Submerged Flexible Pavement Using Laboratory Simulation of Hot Mix Asphalt Concretes}

For purpose of characterization, the simulated fatigue life was measured in terms of the number of load applications that a flexible pavement can accommodate before failure represented as shown in Equations 7 below according to Asphalt Institute (1982);

$$
N_{f}=0.00796\left(\varepsilon_{t}\right)^{-3.291}(E)^{-0.854}
$$

Where;

$\mathrm{Nf}=$ Number of load applications to failure $=$ fatigue life

$\varepsilon \mathrm{t}=$ Horizontal tensile strain at the bottom of asphalt bound layer

$\mathrm{E}=$ Asphalt Concrete Stiffness Modulus (PSI)

Note: Elastic Modulus of asphalt concretes were obtained by applying Equation 8 as proposed by McLeod (1967) as presented below;

$$
E=40 *\left(\frac{\text { Stablity }}{\text { Flow }^{2}}\right)
$$

Where:

Stability $=\mathrm{N}$

Flow $=\mathrm{mm}$ 
Response of Material Properties of Flexible Pavements to Moisture Resulting from Poor Drainage Conditions: Case of Niger Delta Region of Nigeria

\section{RESULTS (TABLES AND FIGURES)}

Table1. Material Property Classification Test Results

\begin{tabular}{|c|c|c|c|c|c|}
\hline & Materials & Asphalt Cement & Gravel & Sand & $\begin{array}{c}\text { Asphalt } \\
\text { Concrete }\end{array}$ \\
\hline Tests & & & & & \\
\hline Specific Gravity & & 48 (i.e. 40/50) & & & \\
\hline $\begin{array}{c}\text { Penetration Grade of } \\
\text { binder (mm) }\end{array}$ & & 127 & & & \\
\hline Viscosity of binder (Secs) & & 51.5 & & & \\
\hline $\begin{array}{c}\text { Softening Point of binder } \\
\text { (C) }\end{array}$ & & & 55 & 45 & \\
\hline Mix Proportion used (\%) & & & & & HEAVY \\
\hline Category of Traffic & & & & & \\
\hline
\end{tabular}

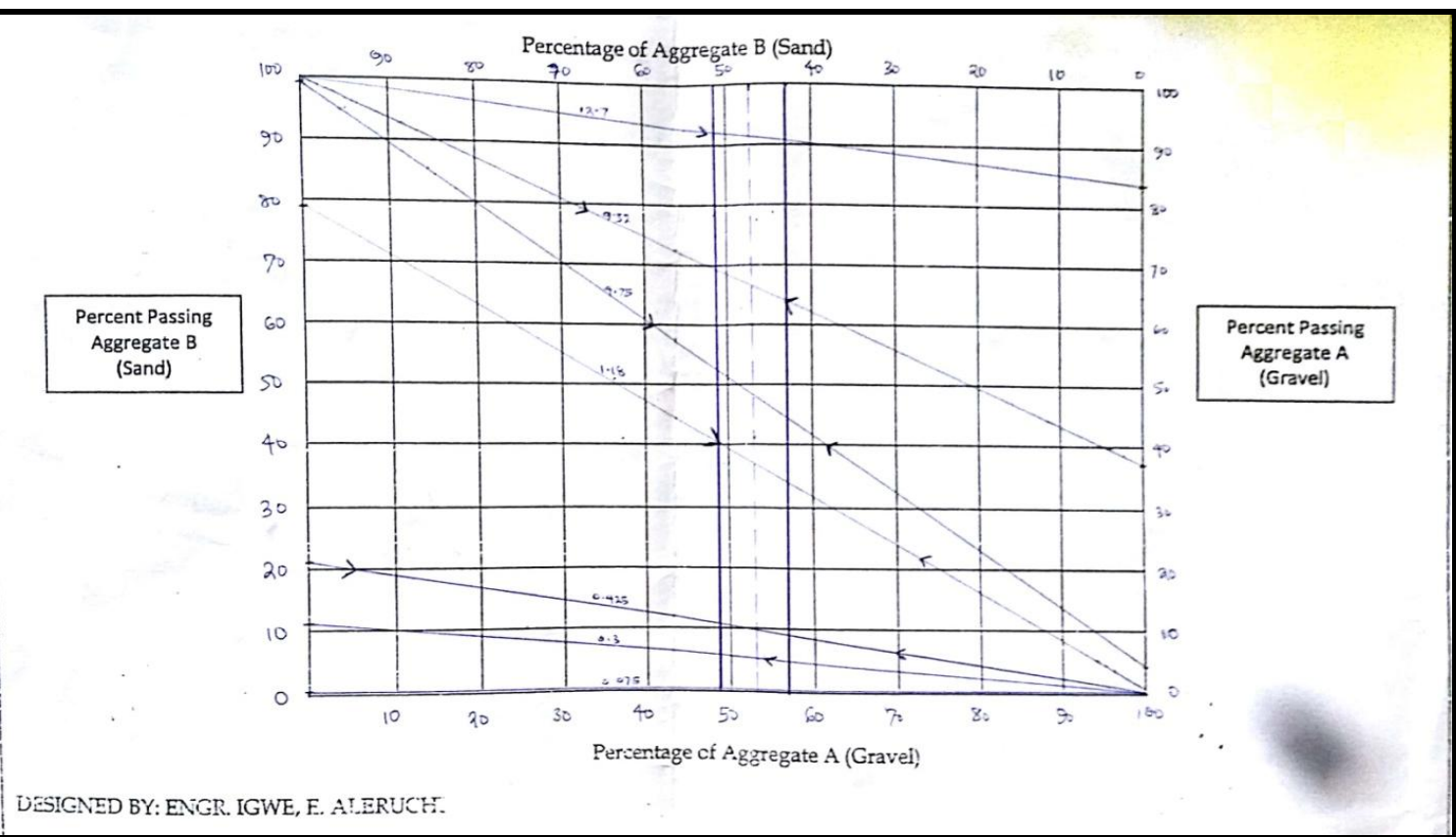

Figure1. Mix proportion of Coarse and Fine Aggregates by blending

Note: Coarse Aggregates (55\%) and Fine Aggregates (45\%)

Table2. Laboratory Test Result of Sample Specimens Weight due to submergence

\begin{tabular}{|l|l|l|r|}
\hline $\begin{array}{l}\text { Duration of soaking } \\
\text { (Days) }\end{array}$ & $\begin{array}{l}\text { Weight of sample in air } \\
\text { by volume }\left(\mathrm{cm}^{3}\right)\end{array}$ & $\begin{array}{l}\text { Weight of sample in } \\
\text { water by volume }\left(\mathrm{cm}^{3}\right)\end{array}$ & $\begin{array}{l}\text { Volume changes } \\
\left(\mathrm{W}_{\mathrm{a}}-\mathrm{W}_{\mathrm{w}}\right) \\
\left(\mathrm{cm}^{3}\right)\end{array}$ \\
\hline 0 & 1180.4 & 644.1 & 536.3 \\
\hline 1 & 1185.7 & 644.0 & 541.7 \\
\hline 2 & 1186.6 & 642.0 & 544.6 \\
\hline 3 & 1192.7 & 641.8 & 550.9 \\
\hline 4 & 1195.8 & 640.4 & 555.4 \\
\hline 5 & 1196.4 & 637.9 & 558.5 \\
\hline
\end{tabular}

Table3. Laboratory Test Results of Mix Design and Elastic Properties

\begin{tabular}{|c|c|c|c|c|}
\hline $\begin{array}{c}\text { Duration of } \\
\text { soaking (Days) }\end{array}$ & Stability (N) & Flow (mm) & Flow (inches) & Density $\left(\mathrm{kg} / \mathrm{m}^{3}\right)$ \\
\hline 0 & 21950 & 10.2 & 0.408 & 2201.007 \\
\hline 1 & 19670 & 10.44 & 0.4176 & 2188.85 \\
\hline 2 & 18660 & 11.28 & 0.4512 & 2178.847 \\
\hline 3 & 17990 & 12.24 & 0.4896 & 2165.003 \\
\hline 4 & 16210 & 12.72 & 0.5088 & 2153.043 \\
\hline 5 & 14010 & 13.92 & 0.5568 & 2142.167 \\
\hline
\end{tabular}


Response of Material Properties of Flexible Pavements to Moisture Resulting from Poor Drainage Conditions: Case of Niger Delta Region of Nigeria

Table4. Determination of Durability Indices due to submergence

\begin{tabular}{|c|c|c|c|c|}
\hline $\begin{array}{c}\text { Duration of } \\
\text { soaking (Days) }\end{array}$ & $\begin{array}{c}\text { Swell Index (\%) } \\
\text { (Equation 4) }\end{array}$ & $\begin{array}{c}\text { Retained Stability } \\
(\mathrm{N})\end{array}$ & $\begin{array}{c}\text { Retained Stability } \\
\text { Index (\%) } \\
\text { (Equation 5) }\end{array}$ & $\begin{array}{c}\text { First Durability } \\
\text { Index (\%) } \\
\text { (Equation 6) }\end{array}$ \\
\hline 0 & 0 & 21950 & 100 & \multirow{3}{*}{36.17} \\
\hline 1 & 1.01 & 19670 & 89.61 & \\
\hline 3 & 1.55 & 18660 & 85.01 & 81.96 \\
\hline 4 & 2.72 & 17990 & 73.85 & \\
\hline 5 & 3.56 & 16210 & 63.83 & \\
\hline
\end{tabular}

Table5. Determination of Elastic properties and Fatigue due to submergence

\begin{tabular}{|c|c|c|c|c|c|}
\hline $\begin{array}{l}\text { Duration of } \\
\text { soaking } \\
\text { (Days) }\end{array}$ & $\begin{array}{l}\text { Tensile } \\
\text { Strain }\end{array}$ & $\begin{array}{c}\text { Elastic Modulus } \\
\left(\mathrm{N} / \mathrm{mm}^{2}\right) \\
(\text { Equation } 8)\end{array}$ & $\begin{array}{l}\text { Elastic } \\
\text { Modulus } \\
\left(\mathrm{lb} / \mathrm{in}^{2}\right) \\
\end{array}$ & $\begin{array}{c}\text { Fatigue (20yrs) } \\
\text { (Equations 7) }\end{array}$ & $\begin{array}{c}\text { Design } \\
\text { Vehicles per } \\
\text { day } \\
\end{array}$ \\
\hline 0 & 0.000254 & 8439.062 & 1223985 & 343386 & 47 \\
\hline 1 & 0.000266 & 7218.772 & 1046996 & 336690 & 46 \\
\hline 2 & 0.00031 & 5866.154 & 850815.2 & 241531 & 33 \\
\hline 3 & 0.000365 & 4803.174 & 696642.7 & 167356 & 23 \\
\hline 4 & 0.000394 & 4007.456 & 581233.4 & 151656 & 21 \\
\hline 5 & 0.000472 & 2892.142 & 419470.5 & 110695 & 15 \\
\hline
\end{tabular}

Note: $1 \mathrm{~N} / \mathrm{mm}^{2}=145.038 \mathrm{lb} / \mathrm{in}^{2}$

Table6. Summary of Percentage Changes in Material Properties of Concrete between 0-5 Days

\begin{tabular}{|c|c|c|c|c|c|}
\hline $\begin{array}{c}\text { Material } \\
\text { Property }\end{array}$ & Index of Swell & Tensile Strain & $\begin{array}{l}\text { Index of } \\
\text { Retained } \\
\text { Stability }\end{array}$ & Elastic Modulus & Fatigue \\
\hline $\begin{array}{c}\text { Percentage } \\
\text { Change (\%) }\end{array}$ & +4.1 & +85.8 & -36.2 & -65.7 & -67.7 \\
\hline
\end{tabular}

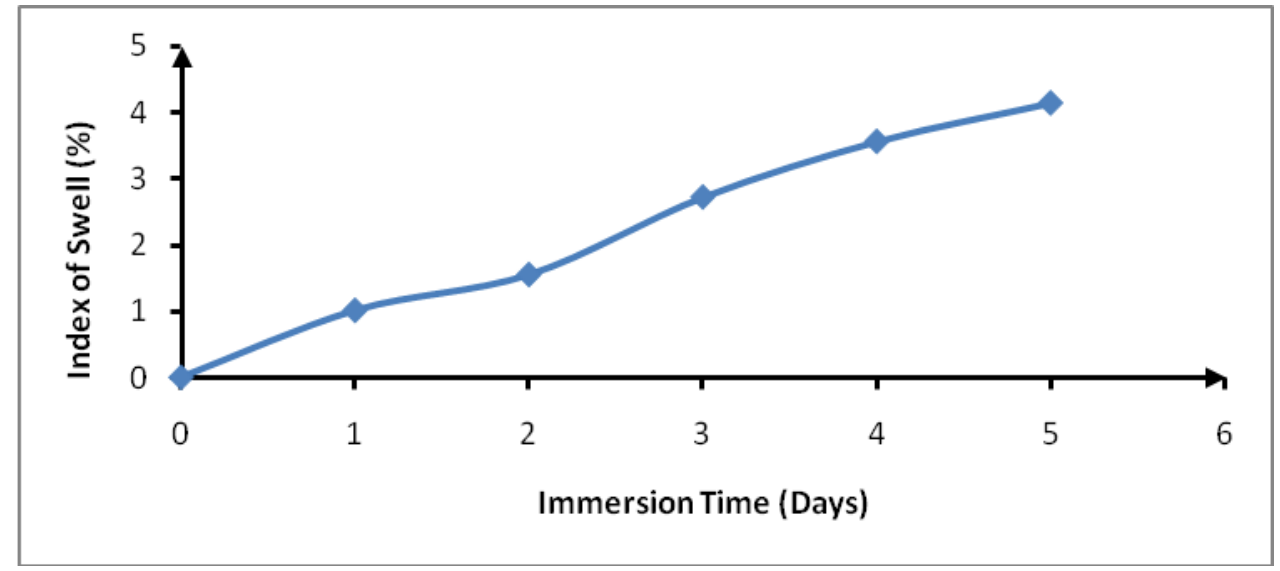

Figure2. Variation of Index of Swell with Immersion Time

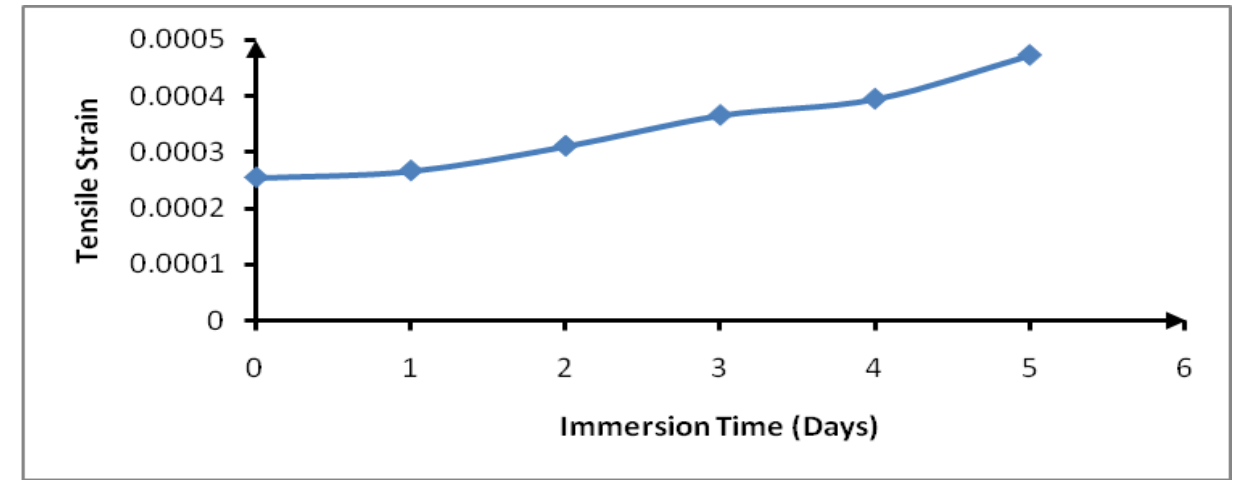

Figure3. Variation of Tensile Strain with Immersion Time 
Response of Material Properties of Flexible Pavements to Moisture Resulting from Poor Drainage Conditions: Case of Niger Delta Region of Nigeria

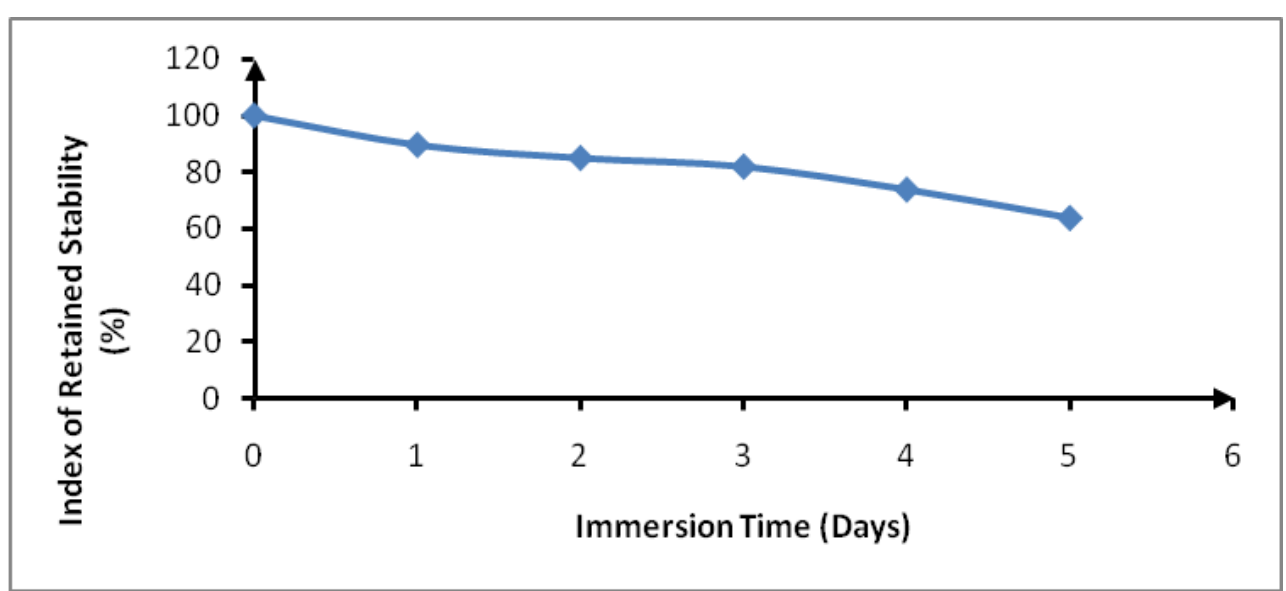

Figure4. Variation of Index of Retained Stability with Immersion Time

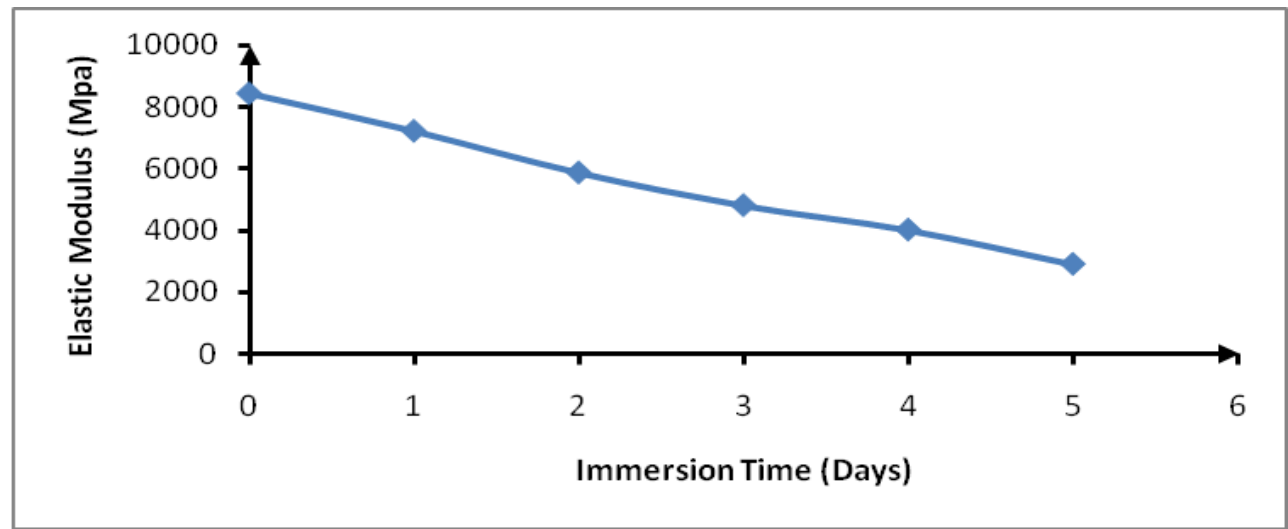

Figure5. Variation of Elastic Modulus with Immersion Time

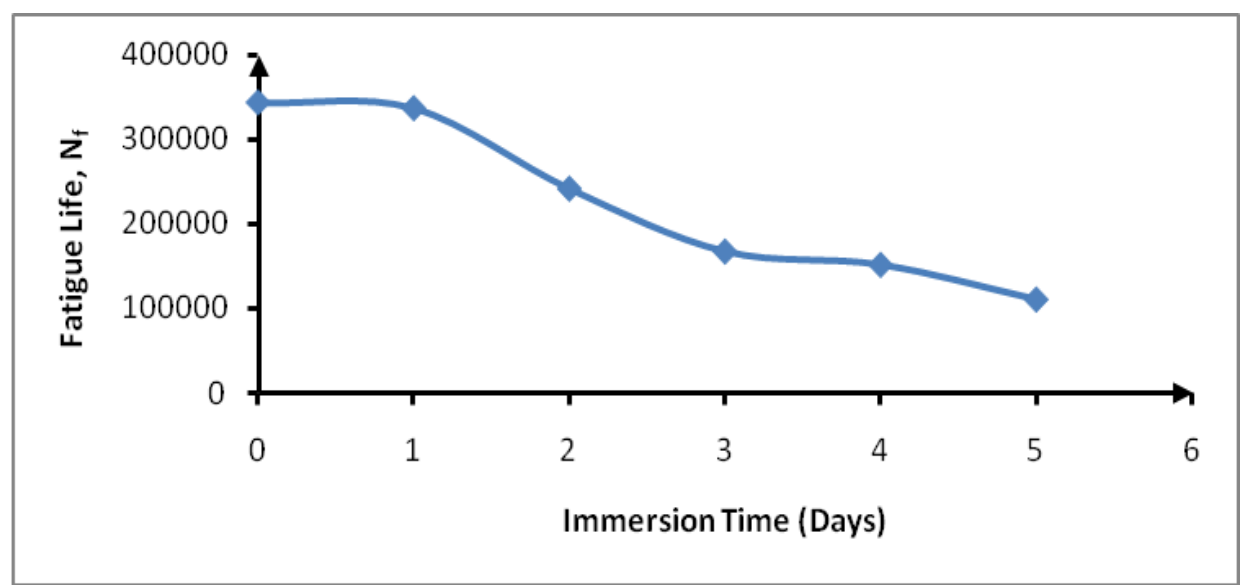

Figure6. Variation of Fatigue Life with Immersion Time

\section{Discussions}

Results from the laboratory simulation of asphalt concrete mixes representing typical flexible pavements submerged under moisture for duration of 5 days revealed the following;

- Pavement submergence up to 5 days resulted in continuous swell due to moisture absorption leading to aggregate - binder separation, pavement deterioration and ultimately failure (see Figure2)

- Pavement submergence up to 5 days resulted in loss of stability therefore reducing load carrying capacity of pavement within design period indicative of reduced index of retained stability (see Figure 4)

- Pavement submergence up to 5 days resulted in reduced elastic modulus (see Figure 5)

- Pavement submergence up to 5 days resulted in reduced pavement fatigue life (see Figure 6) 
Response of Material Properties of Flexible Pavements to Moisture Resulting from Poor Drainage Conditions: Case of Niger Delta Region of Nigeria

\section{CONCLuSions}

From the results and analysis of the laboratory simulation carried out on asphalt concretes representing typical flexible pavements it was concluded that;

- Moisture effect on flexible pavement material properties are grossly jeopardized should pavements be allowed to experience submergence due to improper drainage provisions.

- Government should give proper attention to design, construction and maintenance of drainage infrastructures with respect to specified standards which can be achieved through proper award of contracts, monitoring, supervision and execution of works.

- Government should ensure through the use of task force or other Government Agencies the regular cleaning of drainages and enact executable laws that will prohibit dumping of refuse into drains as well as building of structures across drainage paths.

\section{REFERENCES}

[1] Asphalt Institute (1981) “Thickness Design-Asphalt Pavements for Highways and Streets”, Manual Series No. 1.

[2] Asphalt Institute (1982) Thickness Design Manual. Research Report 82-2, Lexington, Ky.

[3] Asphalt Institute (1984) Manual Series N0.2 (MS-2)

[4] Craus, J., Ishai, I., and Sides, A. (1981) Durability of bituminous paving mixtures as related to filler type and properties (with discussion), In: Association of Asphalt Paving Technologists Proceedings. Vol. 50.

[5] Emesiobi, F. C. (2000) Bitumen and Tars: Testing and Quality Control of Materials in Civil and Highway Engineering. Port Harcourt, Nigeria, Blue Print Limited; p. 231

[6] Igwe, E. A.; Ayotamuno, M. J.; Okparanma, R. N.; Ogaji, S. O. T.; and Probert,S. D. (2009) „Road Surface Properties affecting Rates of Energy Dissipation from Vehicles" Journal of Applied Energy, vol. 86, pp. 1692-1696, Elsevier Publishing.

[7] Kim, Y. R. (2008) "Modeling of Asphalt Concrete", Chapter 1.

[8] Lee, D.Y. (1969) Durability and Durability Tests for Paving Asphalt: A State of the Art Report. Engineering Research Institute, Iowa State University.

[9] McLeod, N.W. (1967) Asphalt Institute Layer Equivalency Program. College Park, MD, Research Series 15.

[10] Mehari, Z. B. (2007) "Effect of Different Types of Filler Materials on Characteristics of HotMix-Asphalt Concrete", A thesis submitted to School of Graduate Studies of Addis Ababa University in partial fulfillment of the requirements for the degree of Master of Science in Civil Engineering (Road and Transport Engineering)

[11] National Asphalt Pavement Association (1982) "Development of Marshall Procedures for Designing Asphalt Paving Mixtures", Information Series 84, National Asphalt Pavement Association Lanham, MD.

[12] NationMaster@http://www.nationmaster.com/country- info/stats/Transport/Roads/Paved/\%of-totalroads: accessed online on July 19, 2016.

[13] Putri, A.M., Suparma, L.B. (2010) Laboratory study on the durability characteristics (moisture damage evaluation) of Asphalt Concrete Wearing Course (AC-WC) utilizing Bantak and Dereng as aggregate (using Marshall methods), J Eastern Asia Soc Transport Study; 8: 1555-67p.

[14] Robbins, M. M. (2009) "An investigation into dynamic complex modulus of Hot Mix Asphalt an it"s contributing factor" Thesis presented to the Department of Civil Engineering, University of Toledo, USA, MSc Civil Engineering, Directed by David H. Timm.

[15] Roberts, F. L. Kandhal, P. S., Brown, E. R.; Lee, D. Y. and Kennedy, T. W., (1996) "Hot Mix Asphalt Materials, Mixture Design, and Construction" National Asphalt Pavement Association Education Foundation Lanham, MD.

Citation: Enwuso Aleruchi Igwe, "Response of Material Properties of Flexible Pavements to Moisture Resulting from Poor Drainage Conditions: Case of Niger Delta Region of Nigeria", International Journal of Constructive Research in Civil Engineering, 5(4), pp. 13-22. DOI: http://dx.doi.org/10.20431/24548693.0504003 .

Copyright: (0) 2019 Authors, This is an open-access article distributed under the terms of the Creative Commons Attribution License, which permits unrestricted use, distribution, and reproduction in any medium, provided the original author and source are credited. 